\title{
Optimisation of properties of silicon carbide ceramics with the use of different additives
}

\author{
K.Lobach $^{1}$, Y.Kupriiyanova ${ }^{1}$, I.Kolodiy $^{1}$, S.Sayenko $^{1}$, \\ V.Shkuropatenko ${ }^{1}$, V.Voyevodin $^{1}$, A.Zykova $^{1}$, A.Bykov $^{2}$, \\ O.Chunyayev $^{2}$, L.Tovazhnyanskyy ${ }^{2}$
}

${ }^{1}$ National Science Center Kharkiv Institute of Physics and Technology, 1 Akademicheskaya Str., 61108 Kharkiv, Ukraine

${ }^{2}$ National Technical University "Kharkiv Polytechnic Institute",

2 Kyrpychova Str., 61002 Kharkiv, Ukraine

\section{Received March 7, 2018}

The influence of different additions on the densification behavior of SiC based ceramics has been investigated. The SiC matrices reinforced by additives of amorphous $\mathrm{B}, \mathrm{Cr}, \mathrm{Si}$ were fabricated using High Speed Hot Pressing Method. Additives content was in the range from 0.5 to $3 \mathrm{wt}$. \%. Microstructural characteristics of silicon carbide ceramics were analyzed by X-ray diffraction, scanning electron microscopy and elemental distribution analyses. A fine-grained and dense ceramics with advanced mechanical properties were produced at optimal processing conditions. SiC ceramics with $\mathrm{Cr}$ and $\mathrm{Si}$ additives possess the best structural and mechanical characteristics: micro hardness 28.0-30 GPa and fracture toughness $K_{1 C}=6.2-4.7 \mathrm{MPa} \cdot \mathrm{m}^{1 / 2}$, respectively. The sintering process by High-Speed Hot Pressing Method leads to the fine-grained structure formation and increase of the fracture toughness of ceramics. The structural and mechanical properties of SiC ceramics can be improved by effective additives content controlling.

Keywords: silicon carbide, nuclear, ceramics, sintering, micro hardness, fracture toughness.

Исследовано влияние различных добавок на механизмы уплотнения керамики на основе SiC. Матрицы SiC, армированные добавками аморфного B, Cr, Si, изготовлены методом высокоскоростного горячего прессования. Содержание добавок находилось в диапазоне от 0,5 до 3 мас.\%. Микроструктурные характеристики керамики карбида кремния проанализированы с помощью рентгеновской дифракции, сканирующей электронной микроскопии и анализа распределения элементов. Определены оптимальные условия процесса изготовления мелкозернистой и плотной керамики с улучшенными механическими свойствами. SiC-керамика с добавками $\mathrm{Cr}$ и $\mathrm{Si}$ обладает лучшими структурными и механическими характеристиками: микротвердостью 28.0-30 ГПа и коэффициентом трещиностойкости $K_{1 C}=6.2-4.7 \mathrm{MПа} \cdot \mathrm{M}^{1 / 2}$ соответственно. Процесс спекания методом высокоскоростного горячего прессования приводит к образованию мелкозернистой структуры и повышению трещиностойкости керамики. Структурные и механические свойства SiC-керамики могут быть улучшены путем әффективного контроля содержания добавок. 
Оптимізація властивостей кераміки карбіду кремнію з використанням різних добавок. К.В.Лобач, Ю.Е.Купріянова, І.В.Колодій, С.Ю.Саєнко, В.А.Шкуропатенко, В.М.Воєводін, Г.В.Зикова, А.О.Биков, О.М.Чуняєв, Л.Л.Товажнянський.

Досліджено вплив різних добавок на механізми ущільнення кераміки на основі $\mathrm{SiC}$. Матриці SiC, армовані добавками аморфного B, Cr, Si, виготовлено з використанням методу високошвидкісного гарячого пресування. Концентрація добавок знаходилася у діапазоні від 0,5 до 3 мас.\%. Мікроструктурні характеристики кераміки карбіду кремнію проаналізовано за допомогою рентгенівської дифракції (XRD), скануючої електронної мікроскопії (SEM) і аналізу розподілу елементів (EDX). Визначено оптимальні умови процесу виготовлення дрібнозернистої і щільної кераміки з поліпшеними механічними властивостями. SiC-кераміка з добавками $\mathrm{Cr}$ i Si демонструє кращі структурні і механічні характеристики: мікротвердість 28,0-30 ГПа і коефіцієнт тріщиностійкості $K_{1 C}=6,2-4,7 \mathrm{MПа} \cdot \mathrm{M}^{1 / 2}$ відповідно. Процес спікання методом високошвидкісного гарячого пресування призводить до утворення дрібнозернистої структури $\mathrm{i}$ підвищення тріщиностійкості кераміки. Структурні і механічні властивості SiC-кераміки можуть бути поліпшені шляхом ефективного контролю вмісту добавок.

\section{Introduction}

In view of the post-accident effects in the nuclear reactors, novel technologies are being developed to improve the safety and economics of nuclear fuels for reactors. Since the event at Fukushima Daiichi in 2011, new concepts were proposed for application in light water reactors (LWRs) with the aim to increase safety margins during accidental conditions. Standard fuel comprises uranium dioxide ceramic pellets sealed in a zirconium alloy cladding tube. There was recorded that advanced fuel materials and designs could provide greater levels of accident tolerance. The Accident Tolerant Fuels (ATF) programme was launched with the aim of finding alternative fuel and cladding materials with optimal operating parameters under normal conditions and enhanced performance during accidents. Dense silicon carbide ( $\mathrm{SiC}$ ) ceramics and composites are very attractive engineering ceramics at the high thermo mechanical conditions, in particular for high temperature and nuclear applications. Due to extremely high binding energy about $5 \mathrm{eV}$, SiC ceramics demonstrate high chemical and radiation resistance. Superior stability of SiC under high temperature steam to that of metal is critical motivation for light water reactor application $[1,2]$.

Composites based on silicon carbide ceramics have been a long-time candidate materials for accident tolerant fuel claddings programme for years [3-5]. SiC ceramics were of great interest in other fields due to its oxidation resistance and strength at high temperatures, both of which are a valuable attribute for an ATF cladding. Silicon carbide ceramic composites have been proposed as a potential cladding material [6] and also as channel boxes for boiling water reactors [7]. Compare to zirconium alloy, $\mathrm{SiC}$ has principal advantages during accident conditions, such as resistance to irradiation and significant oxidation resistance up to $1200-1500^{\circ} \mathrm{C}$ under accident conditions. SiC composite claddings demonstrate very good high temperature properties and dimensional stability. In addition, SiC composites possess high strength at 1200$1500^{\circ} \mathrm{C}$ and thermal conductivity, acceptable neutron absorption cross sections better about $25 \%$ than the zirconium alloys [8-11].

The main advantages for using $\mathrm{SiC}$ to improve accident tolerance are following:

- High melting temperature $-2730^{\circ} \mathrm{C}$;

- Low nominal and high temperature steam corrosion kinetics;

- Low heat of oxidation and oxidation rate.

The oxidation behaviour of $\mathrm{SiC}$ in water vapour containing environments was examined in detail [12]. SiC exhibits exceptional oxidation resistance in water vapour up to $1700^{\circ} \mathrm{C}$. Even in the high pressure conditions, the oxidation rate of $\mathrm{SiC}$ is well below that of Zr-based alloys. This attribute, combined with high-temperature strength of these materials, proves them as one of the leading ATF cladding candidates under examination. The oxidation of SiC has been studied in a variety of gaseous environments [13]. Of particular interest for the nuclear industry is oxidation resistance in a water/steam environment [14]. It has been shown, that radiation significantly affects important material properties relevant to it as a fuel cladding [15]. Sintering and properties of $\mathrm{SiC}$ materials with incorporated additives had been widely studied. Carbides are extensively used in applications that demand corrosion, wear and radiation resistance. The excellent resistance 
exhibited by the carbides is due to their unique combination of high hardness and fracture toughness. The bulk mechanical properties and unique resistance of carbides are strongly affected by their composition and microstructural parameters [16, 17]. The different additives, such as oxides, Si, $\mathrm{B}$, transitional metals of IV-VI subgroups, as sintering activators were added to improve the sintering and fracture toughness of SiC ceramics. The mechanism of ceramics sintering is depended on the powder particle sizes, distribution of the additives, and sintering process parameters. The effect of additives on the ceramic sintering mechanism relates to its content and uniformity. The distribution of additives is very important factor during sintering process. The uniform distribution of additives is beneficial for improving the densification and microstructure formation during the sintering procedure [18-21]. The main approach to enhance the mechanical properties and fracture toughness is sintering of materials with dense and uniform grain microstructure.

The aim of the present study was the effects of the different additives on the microstructural and mechanical properties of $\mathrm{SiC}$ ceramics for high-temperature and nuclear applications.

\section{Experimental}

The highly dispersed powders were used as alloying additives for producing ceramics based on silicon carbide ( $\mathrm{SiC}$ ): $\mathrm{SiC}$ powders of the grade 440 NDP (Superior Graphite Co) with a predominant particle size $0.44 \mu \mathrm{m}$ were chosen as primary material, and powders of $\mathrm{B}$ (amorphous), $\mathrm{Si}$, and $\mathrm{Cr}$, with a predominant particle size $<3 \mu \mathrm{m}$ as additives. The optical microscopy images of powders are presented in Fig. 1. The powders were added to the mixture with the carbon additions in an amount of 0.5 to 3 wt. \%.

Mixing of the initial powders was carried out in a planetary mono-mill "Pulverisette 6" (Germany) in isopropyl alcohol medium with a rotation speed of $300 \mathrm{rpm}$ during $3 \mathrm{~h}$.

Forming and sintering of the samples were made by the method of high-speed hot pressing in vacuum in a graphite mold. The equipment was developed in NSC KIPT in the framework of joint collaboration project (STCU P-154) with Argon National Laboratory and Superior Graphite Co (USA). The optimum process parameters were previously determined and described [22]: sintering temperature $2050^{\circ} \mathrm{C}$, pressure
$40 \mathrm{MPa}$ and holding time $30 \mathrm{~min}$. The samples size was $25 \times 25 \times 4 \mathrm{~mm}^{3}$.

The open porosity and density of the samples were determined by hydrostatic weighing method.

The diffractometry was carried out using a DRON-4-07 X-ray diffractometer in copper $\mathrm{Cu}-\mathrm{K}_{\alpha}$ radiation using a $\mathrm{Ni}$ selectively absorbing $\beta$-filter. The diffracted radiation was detected by a scintillation detector.

The hardness tests of SiC ceramic samples were made on a AMH-3 microhardometer by indentation of a four-sided 136-degree Vickers diamond pyramid. The optimal load value was chosen $9.8 \mathrm{~N}$. The hardness calculations were carried out according to the standard procedure with the measurement of the diagonals of the print:

$$
H_{V}=P / d^{2},
$$

where $H_{V}$ is hardness, $P$ is the load on the indenter, $d^{2}$ is the square of the diagonals of the indentor's print.

The measurements of fracture toughness of ceramic carbide are complicated because of high brittleness of these materials. Estimation of fracture toughness values was made at $9.8 \mathrm{~N}$ load conditions. The equations of fracture toughness of ceramic brittle materials, which are in a good agreement with experimental data, were formulated by Evans, Charles and Wilshaw [23] and by Niihara [24]. Equations for fracture toughness coefficient $\left(K_{1 C}\right)$ calculation were obtained by Niihara semiempiric dependence, commonly used for brittle ceramics [24, 25]:

$$
K_{1 C}=\left(0.035 H_{V} a\right)\left(E_{\varphi} / H_{V}\right)^{2 / 5} / \varphi L^{0.5},
$$

where $a$ is the half-diagonal of the indentor's print, $H_{V}$ is the hardness of the material, and $L$ is the length of the radial crack, $E$ is Young modulus, $\varphi$ is the constraint factor $(\approx 3)$.

The microstructure and morphology of the samples were studied by JEM-700F scanning electron microscope. The Energydispersive X-ray spectroscopy (EDS) method with a high-energy electron beam was used for determination of the elements and distribution in the $\mathrm{SiC}-\mathrm{Si}$ and $\mathrm{SiC}-\mathrm{Cr}$ samples.

\section{Results and discussion}

The physical properties and phase composition of SiC ceramic samples with/without alloying additives obtained at the same technological parameters as previously re- 


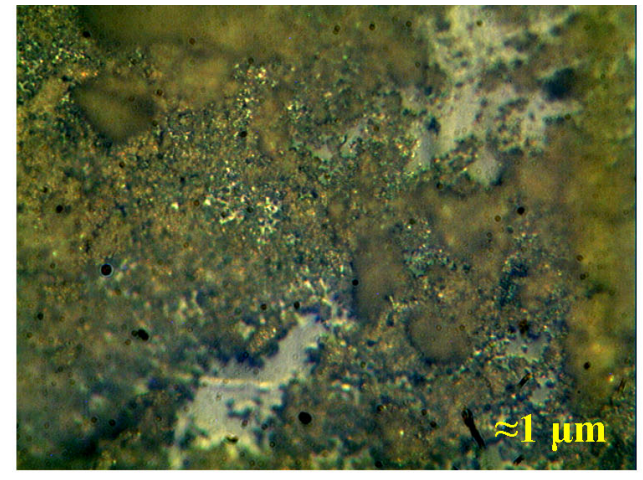

a)

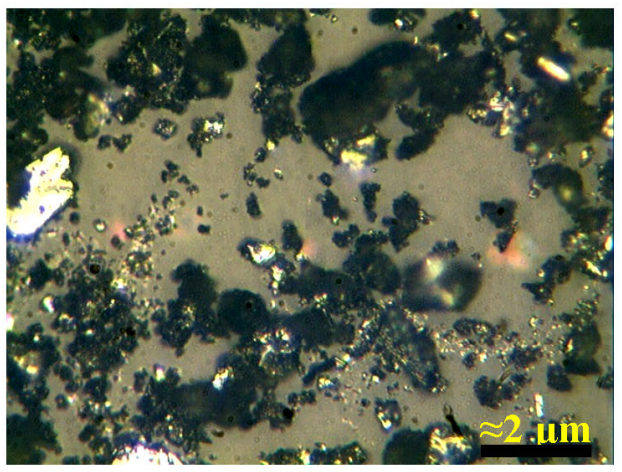

c)

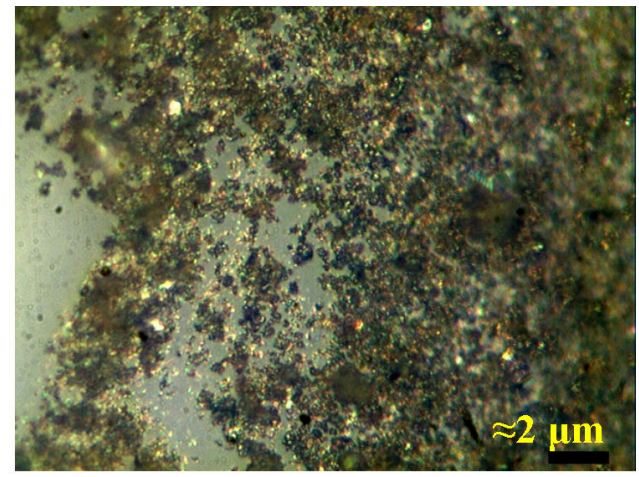

b)

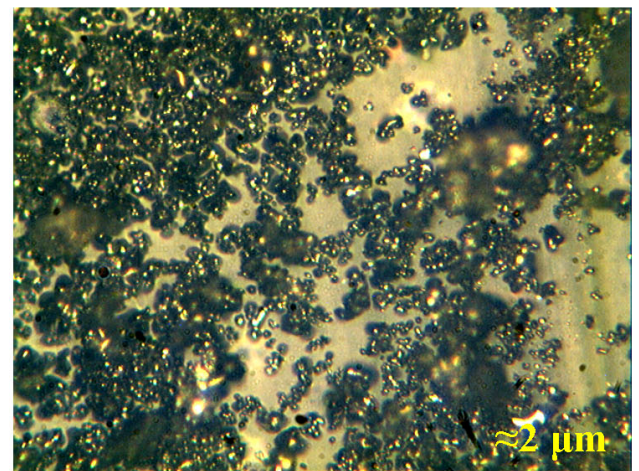

d)

Fig. 1. Images of initial powders: $\mathrm{a}-\mathrm{SiC} ; \mathrm{b}-$ powders of amorphous boron; $\mathrm{c}-$ powders of $\mathrm{Si}$; $\mathrm{d}$ - powders of $\mathrm{Cr}$.

ported [22] were presented in Table 1. Analysis of the data given in Table 1 indicates that a slight decrease in the relative density is observed in SiC ceramic samples with alloying additives: up to $98.4 \%$ (amorphous B), $97.8 \%$ (Cr).

$\mathrm{X}$-ray diffraction analysis of the samples revealed the presence of one phase $\alpha-\operatorname{SiC}$ of polytype-SiC-6H with hexagonal lattice, whereas the introduction of the alloying additives leads to structural changes and the formation of a second $\alpha-S i C$ polytype of silicon carbide-SiC-4H in different weight contents (Table 1, Fig. 2). In addition, the lines of free carbon of different intensity were detected for all ceramics.

Electron microscope images of the fractured cross-sections of the samples $\mathrm{SiC}+$ $1.0 \% \mathrm{Si}+0.3 \% \mathrm{C}$ and $\mathrm{SiC}+0.5 \% \mathrm{Cr}+$ $0.15 \%$ C were presented (Fig. 3, 4). The structure of SiC sample with the Si additives demonstrates a very dense and uniformly fine-grained structure $\mathbf{( 9 9 . 4 \%}$ of the theoretical values). The grain sizes were in the range $0.3-2.2 \mu \mathrm{m}$ with a predominant grain size of $1.5 \mu \mathrm{m}$.
Analysis of SEM/EDX results for SiC + $0.5 \% \mathrm{Cr}+0.15 \% \mathrm{C}$ sample demonstrate that $\mathrm{Cr}$ adding leads to inclusions formation, probably of $\mathrm{Cr}_{n} \mathrm{C}_{x}$ chromium carbide types (Fig. 5). According to small amount of $\mathrm{Cr}$, the presence of phase of $\mathrm{Cr}_{n} \mathrm{C}_{x}$ chromium carbide formation was not detected on XRD patterns of the ceramic samples (Fig. 2c).

The main approach to enhance the mechanical properties and fracture toughness is sintering of materials with dense and uniform grain microstructure. The strength of ceramics increases with the decrease of grain size and porosity.

The hardness tests of $\mathrm{SiC}$ ceramic samples were made by indentation under load condition 9.81 N. Figure 6 shows that at the corners of the indenter prints, cracks appear on all samples, except the sample with the $\mathrm{Cr}$ additives. This fact indicates an increase in the crack resistance and fracture toughness coefficient, which is also confirmed by the calculations carried out according to formula (2). It is known, that Vickers hardness and fracture toughness characteristics are correlated and $H_{V} / K_{1 C}$ ratio is determined the material resistance to surface mechanical damages [25]. Table 2 
K.Lobach et al. / Optimisation of properties of ...

Table 1.Properties and crystalline phases of the SiC samples

\begin{tabular}{||c|c|c|c|c||}
\hline Ceramic composition & $\mathrm{SiC}$ & $\begin{array}{c}\mathrm{SiC}+1.5 \% \mathrm{~B}+ \\
0.75 \% \mathrm{C}\end{array}$ & $\begin{array}{c}\mathrm{SiC}+0.5 \% \mathrm{Cr}+ \\
0.15 \% \mathrm{C}\end{array}$ & $\begin{array}{c}\mathrm{SiC}+1.0 \% \\
0.3 \% \mathrm{Ci}+\end{array}$ \\
\hline Open porosity, $\%$ & 0 & $0-5$ & $0-1$ & $0-1$ \\
\hline Density, g/cm & 3 & 3.19 & 3.15 & 3.16 \\
\hline $\begin{array}{c}\text { Relative density, } \rho, \\
\%\end{array}$ & $99.4 \pm 0.75$ & $98.4 \pm 0.75$ & $97.8 \pm 0.75$ & $99.4 \pm 0.75$ \\
\hline $\begin{array}{c}\text { Phase composition } \\
\mathrm{SiC}-6 \mathrm{H} 99 \% \\
\mathrm{C}-1 \%\end{array}$ & $\begin{array}{c}\mathrm{SiC}-6 \mathrm{H} 45.7 \% \\
\mathrm{SiC}-4 \mathrm{H} 43.5 \% \\
\mathrm{C}-10.7 \%\end{array}$ & $\begin{array}{c}\mathrm{SiC}-6 \mathrm{H} 95.5 \% \\
\mathrm{SiC}-4 \mathrm{H} 2.8 \% \\
\mathrm{C}-1.7 \%\end{array}$ & $\begin{array}{c}\mathrm{SiC}-6 \mathrm{H} 83.8 \\
\mathrm{SiC}-4 \mathrm{H} 16.2 \%\end{array}$ \\
\hline
\end{tabular}
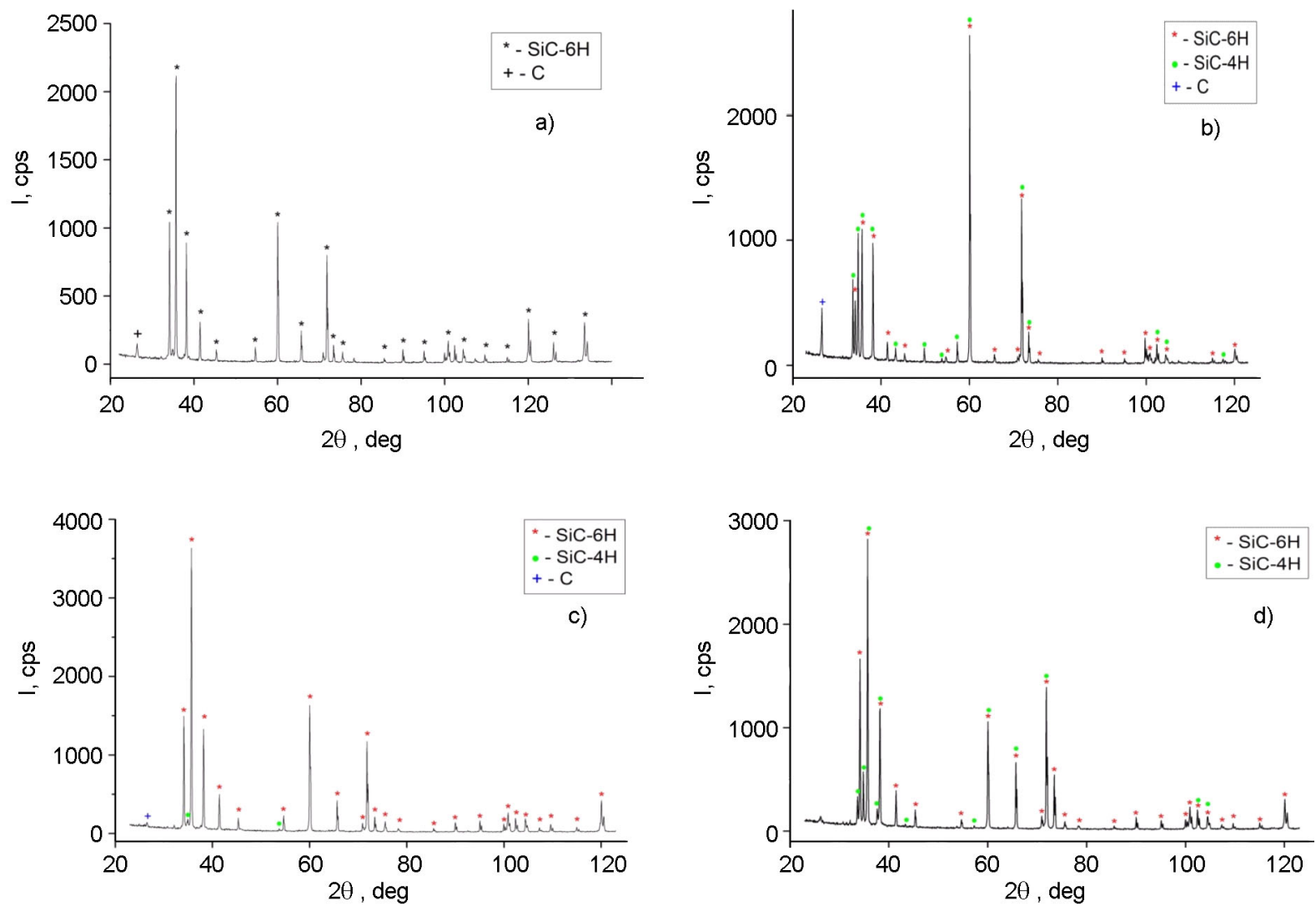

Fig. 2. XRD patterns of the samples: a $-\mathrm{SiC}, \mathrm{b}-\mathrm{SiC}+1.5 \% \mathrm{~B}+\mathbf{0 . 7 5} \% \mathrm{C}$, c $-\mathrm{SiC}+0.5 \%$ $\mathrm{Cr}+0.15 \% \mathrm{C}, \mathrm{d}-\mathrm{SiC}+1.0 \% \mathrm{Si}+0.3 \% \mathrm{C}$.

shows the values for hardness and fracture toughness calculations.

As can be seen from the obtained data, at the similar relative density parameters, the hardness and fracture toughness values are markedly increased especially in samples with additive $\mathrm{Cr}$ and $\mathrm{Si}$. SiC samples without additives produced by High-Speed Hot Pressing Method demonstrate high density and microhardness parameters but low fracture toughness coefficients. There is a problem of manufacturing of thin-wall tubes (claddings) from SiC brittle ceramics. The fracture toughness parameters increase from $K_{1 C}=4.3 \mathrm{MPa} \cdot \mathrm{m}^{1 / 2}$ for $\mathrm{SiC}$ ceramic samples to $K_{1 C}=6.2 \mathrm{MPa} \cdot \mathrm{m}^{1 / 2}$ for $\mathrm{SiC}$ samples with $\mathrm{Cr}$ additives.

The high physical and mechanical properties of $\mathrm{SiC}$ with $\mathrm{Si}$ alloying additives were attributed to a dense structure $(99.4 \%$ of theoretical value) with grain sizes in the range $0.3-2.2 \mu \mathrm{m}$ and a predominant size of $1.5 \mu \mathrm{m}$. In addition, melting temperature of $\mathrm{Si}$ is $1414,85^{\circ} \mathrm{C}$ and more lower than SiC sintering temperature about $2050-2100^{\circ} \mathrm{C}$. This fact results in liquid phase formation on the 

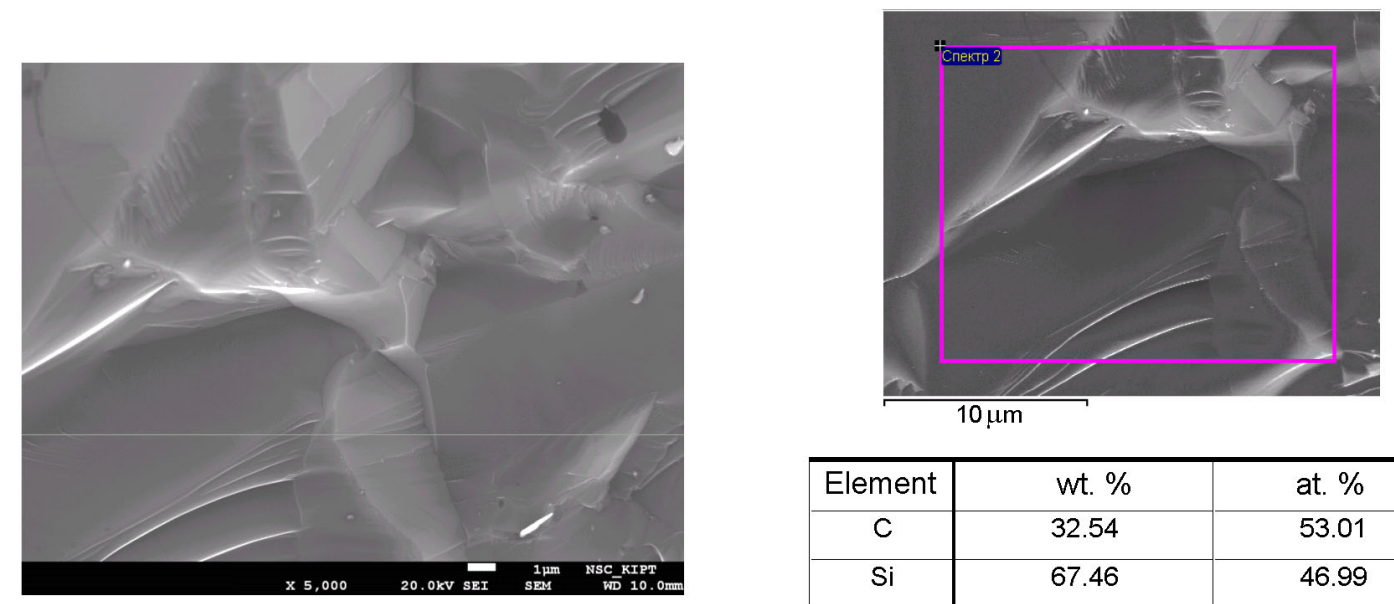

\begin{tabular}{|c|c|c|}
\hline Element & wt. \% & at. \% \\
\hline $\mathrm{C}$ & 32.54 & 53.01 \\
\hline $\mathrm{Si}$ & 67.46 & 46.99 \\
\hline Total & 100.00 & \\
\hline
\end{tabular}

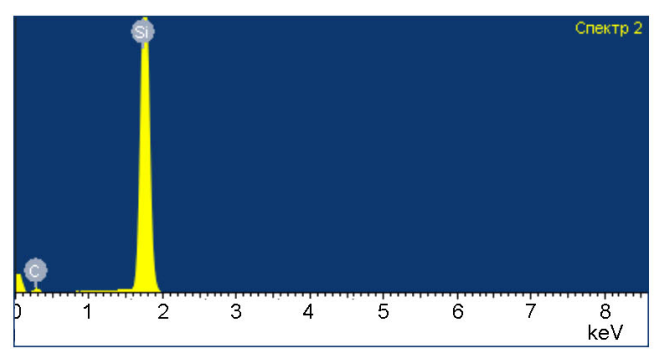

Fig. 3. SEM images and EDX spectra of $(\mathrm{SiC}+1.0 \% \mathrm{Si}+0.3 \% \mathrm{C})$ sample.

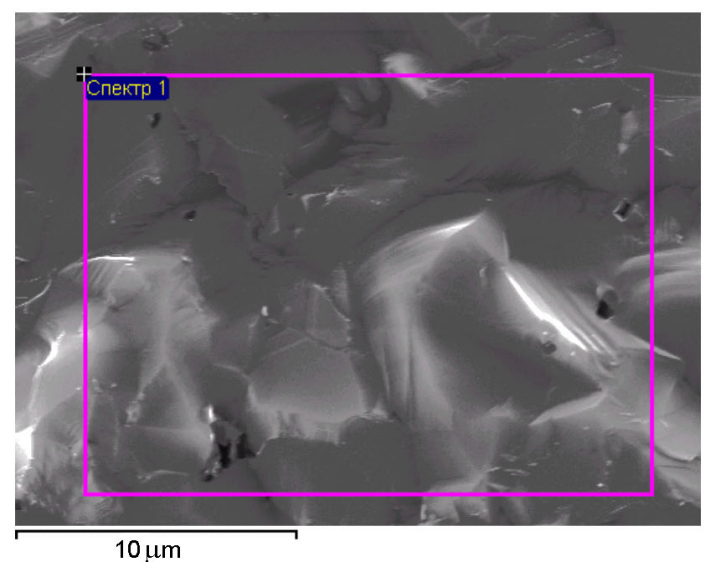

\begin{tabular}{|c|c|c|}
\hline Element & wt. \% & at. \% \\
\hline $\mathrm{C}$ & 17.14 & 33.07 \\
\hline $\mathrm{O}$ & 2.06 & 2.99 \\
\hline $\mathrm{Si}$ & 73.63 & 60.75 \\
\hline $\mathrm{Cr}$ & 7.17 & 3.20 \\
\hline Total & 100.00 & \\
\hline
\end{tabular}

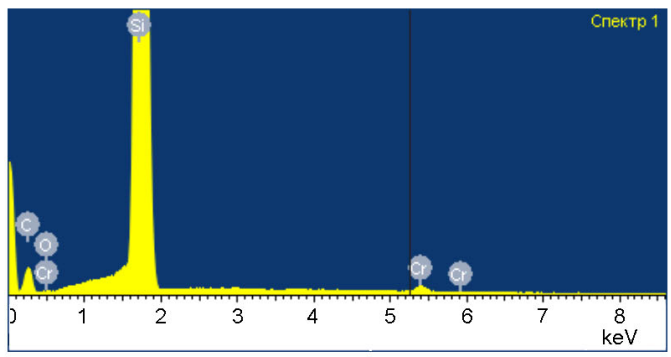

Fig. 4. SEM images and EDX spectra of $(\mathrm{SiC}+0.5 \% \mathrm{Cr}+0.15 \% \mathrm{C})$ sample.

grain boundaries and acceleration of ceramic densification process during sintering.

In contrary, adding of boron additives with melting temperature about $2076^{\circ} \mathrm{C}$ did not lead to liquid phase formation during sintering process and results in lower values of relative density $(98.4 \%$ of theoretical value). The lower density parameters may be attributed to boron oxidation process and boron oxide evaporation at hot pressing temperature conditions.

The uniform distribution of chromium over the ceramic matrices and the formation of carbides were observed (Fig. 5). The uni- 
K.Lobach et al. / Optimisation of properties of ...

Table 2. Values for hardness and fracture toughness calculations

\begin{tabular}{|c|c|c|c|c|c|c|}
\hline Ceramic material & $\underset{\mathrm{N}}{\text { Load } P,}$ & $\begin{array}{c}\text { Crack radius } \\
a, \mu \mathrm{m}\end{array}$ & $\begin{array}{c}\text { Crack length } \\
L, \mu \mathrm{m}\end{array}$ & $\begin{array}{c}\text { Hardness } \\
H_{V}, \mathrm{GPa}\end{array}$ & $\begin{array}{c}\text { Fracture } \\
\text { toughness } K_{1 C}, \\
\mathrm{MPa} \cdot \mathrm{m}^{1 / 2}\end{array}$ & $\begin{array}{c}\text { Ratio } \\
H_{V} \\
10^{3} / K_{1 C}\end{array}$ \\
\hline $\mathrm{SiC}$ & 9.81 & 28.0 & 21.0 & 27.3 & 4.3 & 6.5 \\
\hline $\mathrm{SiC}+1.5 \% \mathrm{~B}+0.75 \% \mathrm{C}$ & 9.81 & 25.50 & 26.0 & 28.2 & 3.6 & 7.8 \\
\hline $\mathrm{SiC}+0.5 \% \mathrm{Cr}+0.15 \% \mathrm{C}$ & 9.81 & 25.80 & 8.90 & 28.0 & 6.2 & 4.5 \\
\hline $\mathrm{SiC}+1.0 \% \mathrm{Si}+0.3 \% \mathrm{C}$ & 9.81 & 24.74 & 15.52 & 30.0 & 4.7 & 6.4 \\
\hline
\end{tabular}

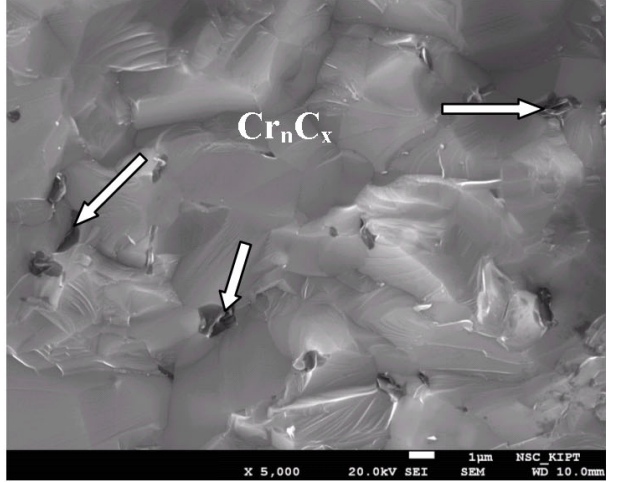

a)

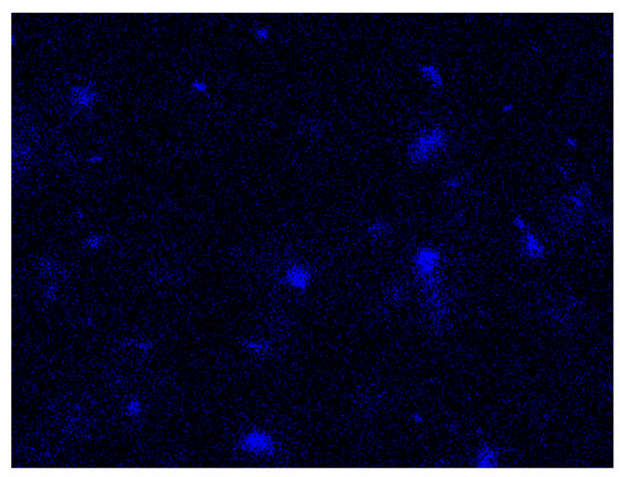

c)

Fig. 5. SEM and EDX images of $(\mathrm{SiC}+0.5 \% \mathrm{Cr}+0.15 \% \mathrm{C})$ sample.

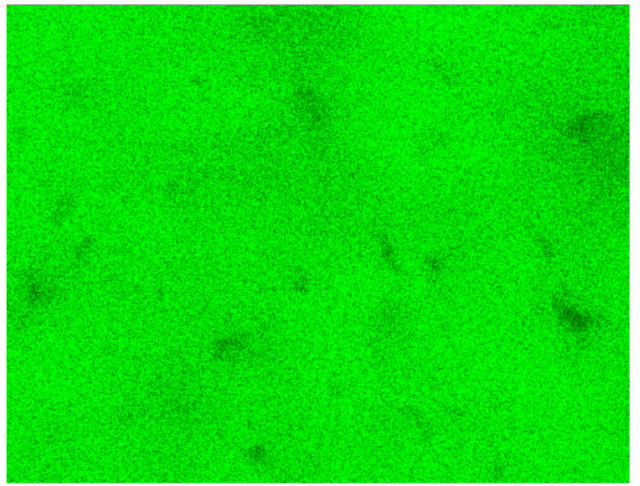

b)

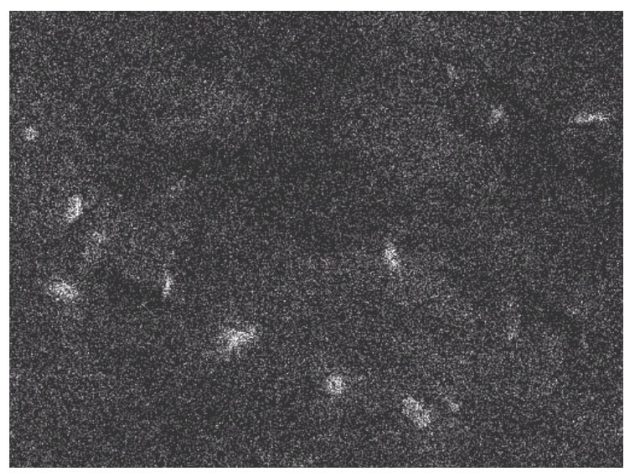

d) form distribution of chromium at the grain boundaries may be due to the fact, that the elasticity of saturated chromium vapor heated in vacuum is several orders of magnitude higher than that of other refractory transition metals [26]. Intensive evaporation rapidly accelerated the mass transfer of chromium in the powder mixture. This effect improves the uniformity of the distribution of chromium and, consequently, improves the speed and uniformity of sintering.

Previously was reported, that dense and uniform SiC ceramics demonstrate high mechanical parameters: micro hardness $24 \mathrm{GPa}$ $[27,28]$ and fracture toughness coefficient $K_{1 C}=5 \mathrm{MPa} \cdot \mathrm{m}^{1 / 2}$ [28]. At present study, $\mathrm{SiC}$ ceramic samples without additives also show high mechanical parameters: micro hardness 27.3 GPa and fracture toughness coefficient $K_{1 C}=4.3 \mathrm{MPa} \cdot \mathrm{m}^{1 / 2}$. Furthermore, a small amount of chromium adding results in significant increase of mechanical properties: microhardness to $28.0 \mathrm{GPa}$ and fracture toughness coefficient up to 6.2 $\mathrm{MPa} \cdot \mathrm{m}^{1 / 2}$.

The mechanism of ceramics sintering is depended on the powder particle sizes, mixing procedure and sintering process parameters. The distribution of additives is very important factor during sintering process. The effect of additives on the ceramic sintering mechanism relates to its content and uniformity. The uniform distribution of additives is beneficial for improving the microstructure formation during the ceramic manufacturing procedure. 


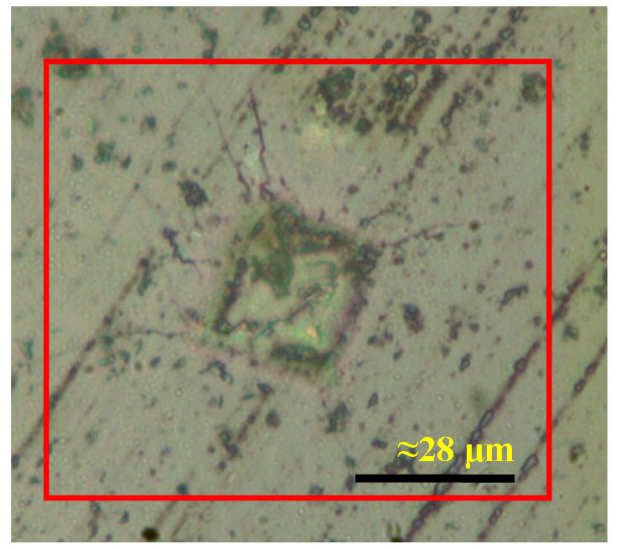

a)

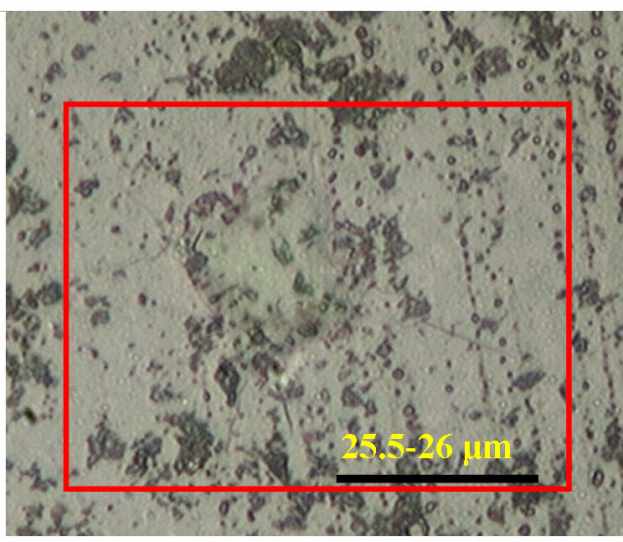

c)

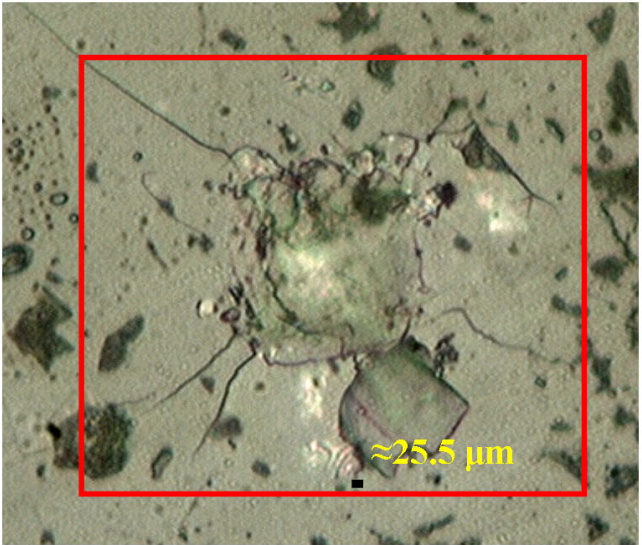

b)

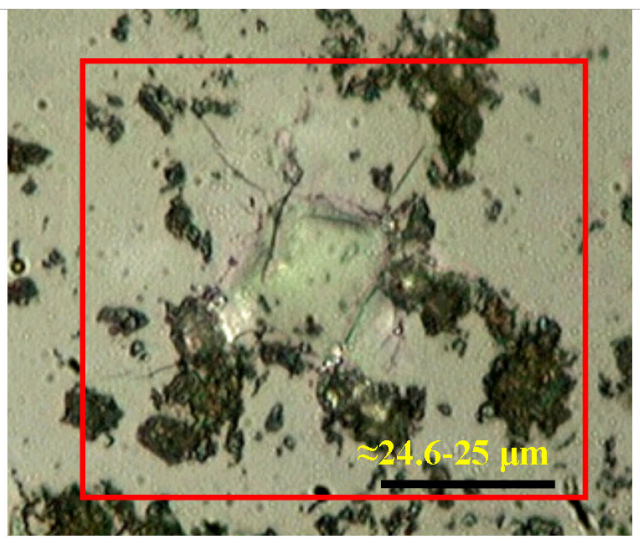

d)

Fig. 6. Images of the indentor's print: $\mathrm{a}-\mathrm{SiC}, \mathrm{b}-\mathrm{SiC}+1.5 \% \mathrm{~B}+0,75 \% \mathrm{C}, \mathrm{c}-\mathrm{SiC}+0.5 \%$ $\mathrm{Cr}+0.15 \% \mathrm{C}, \mathrm{d}-\mathrm{SiC}+1.0 \% \mathrm{Si}+0.3 \% \mathrm{C}$.

\section{Conclusions}

$\mathrm{SiC}$ ceramics are proposed as new claddings materials for nuclear and other branches of science and industries. Ceramic materials based on $\mathrm{SiC}$ with different alloying additives were investigated in this study for further applications in nuclear power industries (nuclear fusion and fission).

Sintering process by High-Speed Hot Pressing Method leads to the fine-grained structure formation and increase of the fracture toughness of ceramics. The results of microcracking under indentation conditions were revealed the increase in hardness and crack resistance of $\mathrm{SiC}$ ceramics with $\mathrm{Cr}$ and $\mathrm{Si}$ additives. In contrast, alloying additive boron in amorphous form has not influenced on the densification process under the sintering conditions, as evidenced by the insufficiently high density of SiC ceramics. In addition, it was demonstrated that samples of $\mathrm{SiC}$ with alloying additives $(0.5 \% \mathrm{Cr}+$ $0.15 \% \mathrm{C})$ and $(1.0 \% \mathrm{Si}+0.3 \% \mathrm{C})$ are characterized by the best structural and mechanical properties: microhardness $-28.0-$ $30.0 \mathrm{GPa}$, fracture toughness coefficient $K_{1 C}=6.2-4.7 \mathrm{MPa} \cdot \mathrm{m}^{1 / 2}$, respectively. The strength of ceramics increases with the uniform and fine-grained structure formation. The samples sintered with $\mathrm{Cr}$ and $\mathrm{Si}$ additives demonstrate fine grain microstructure and advanced mechanical properties, which confirms the advantages of alloying additives using.

The safety and performance benefits from Accident Tolerant Fuels conception will be realized only to the extent that new technologies and materials are widely adopted and applied in operating reactors.

\section{References}

1. L.L.Snead, R.H.Jones, A.Kohyama et al., $J$. Nucl. Mater., 26, 233 (1996).

2. S.Yeo, E.McKenna, R.Baney et al., J.Nucl. Mater., 433, 66 (2013).

3. L.L.Snead, T.Inozawa, Y.Katoh et al., J. Nucl. Mater., 371, 329 (2007). 
4. K.A.Terrani, B.A.Pint, C.M.Parish et al., J. Am.Ceram. Soc., 97, 2331 (2014).

5. M.Ben-Belgacem V. Richet, K.A.Terrani et al., J.Nucl. Mater., 447, 125 (2014).

6. K.Yueh, D.Carpenter, H.Feinroth, Nucl.Eng. Int., 55, 14 (2010).

7. K.Yueh, K.A.Terrani, J.Nucl.Mater., 448, 380 (2014).

8. Y.Katoh, K.Ozawa, C.Shih et al., J.Nucl. Mater., 448, 448 (2014).

9. B.A.Pint, K.A.Terrani, M.P.Brady et al., $J$. Nucl. Mater., 440, 420 (2013).

10. P.F.Tortorelli, K.L.More, J.Am.Ceram.Soc., 86, 1249 (2003).

11. Y.Katoh, L.L.Snead, T.Cheng et al., J.Nucl. Mater., 448, 497 (2014).

12. E.J.Opila, J.Am.Ceram.Soc., 82, 625 (1999).

13. C.H.Henager, Y.Shin, Y.Blum et al., J.Nucl. Mater., 1139, 367 (2007).

14. M.Herrmann, W.Lippmann, A.Hurtado, $J$. Nucl. Mater., 443, 458 (2013).

15. Y.Katoh, L.L.Snead, T.Nozawa et al., J.Nucl. Mater., 403, 48 (2010).

16. J.H.She, K.Ueno, Mater. Res. Bull., 34, 1629 (1999).
17. Z.H.Huang, D.C.Jia, Ceram. Intern., 29, 13 (2003).

18. V.A.Izhevsikyi, L.A.Genova, Intern. J. Refract. Metal \& Hard Mater., 19, 407 (2001).

19. R.P.Jensen, E.W.Luecke, Mater. Sci. Engin.: $A, 282,109$ (2000).

20. Y.W.Kim, J.Y.Kim, J. Eur. Cer. Soc., 20, 945 (2000).

21. E.Liden, E.Carlstrom, J. Amer. Cer. Soc., 78, 1761 (1995).

22. K.Lobach, Ye.Svitlychnyi, S.Sayenko et al., Probl. At.Sci. Techn., 108, 97 (2017).

23. A.G.Evans, E.A.Charles, J. Amer. Cer. Soc., 59, 371 (1976).

24. K.Niihara, R.Morena, D.P.H.Hasselman, $J$. Mater. Sci.Lett., 1, 13 (1982).

25. G.A.Gogotsi, A.V.Bashta, Problemy Prochnosti, 9, 49 (1990).

26. Ye.P.Ponomarenko, A.I.Plyshevskiy, V.K.Suprunchuk, Metallizatsiya Staley i Splavov v Vakuume, Tekhnika, Kiev (1974).

27. J.Wade, P.Claydon, H.Wu, Amer. Cer. Soc., 35, 91 (2015).

28. D.O.Moskovskikh, Y.Song, S.Rouvimov et al., Ceram. Intern., 42, 12686 (2016). 